\title{
Using Airborne Digital Imagery for Detecting Oak Wilt Disease
}

\author{
J. H. Everitt and D. E. Escobar, USDA-ARS, Integrated Farming and Natural Resources Research, Weslaco, TX \\ 78596; D. N. Appel, Department of Plant Pathology and Microbiology, Texas A \& M University, College Station \\ 77843; W. G. Riggs, Texas Agricultural Extension Service, Jourdanton 78026; and M. R. Davis, USDA-ARS, \\ Weslaco, TX
}

\begin{abstract}
Everitt, J. H., Escobar, D. E., Appel, D. N., Riggs, W. G., and Davis, M. R. 1999. Using airborne digital imagery for detecting oak wilt disease. Plant Dis. 83:502-505.

Color-infrared (CIR) digital imagery was evaluated as a remote sensing tool for detecting oak wilt disease in live oak (Quercus fusiformis). Aerial CIR digital imagery and CIR photography were obtained concurrently of a live oak forested area in south-central Texas affected by oak wilt. Dead, diseased, and healthy live oak trees could generally be delineated as well in the digital imagery as in the CIR photography. Light reflectance measurements obtained in the field showed that dead, diseased, and healthy trees had different visible and near-infrared reflectance values.
\end{abstract}

Oak wilt, a disease caused by the vascular fungus Ceratocystis fagacearum, occludes the water-conducting tissues of several species of oak (Quercus spp.). Symptoms include dieback of the upper crown and discoloration and wilting of the foliage $(1,17)$. Oak wilt has periodically caused widespread decline and mortality of live oak (Quercus fusiformis) and several other species of oak in central and southcentral Texas $(2,3,17,18)$.

Color-infrared (CIR) aerial photography has been a useful technique to detect oak wilt disease $(5,12,16,19,24)$. Appel and Maggio (3) used CIR aerial photography to survey oak mortality and to identify oak wilt centers in central Texas. They were able to detect oak wilt in several species of oak, but Spanish oak (Quercus texana Buckley) and live oak were most severely affected. Appel et al. (4) were further able to utilize CIR aerial photography to analyze epidemiological parameters for oak wilt to improve options for disease management.

Within the last few years, aerial videographic and true digital imaging systems

Corresponding author: J. H. Everitt

E-mail: j-everitt@tamu.edu

Trade names are included for the benefit of the reader and do not imply endorsement of or a preference for the product listed by the United States Department of Agriculture.

Accepted for publication 18 March 1999.

Publication no. D-1999-0419-04S

This article is in the public domain and not copyrightable. It may be freely reprinted with customary crediting of the source. The American Phytopathological Society, 1999. have emerged as remote sensing tools $(6,8,13-15)$. These electronic systems offer essentially real-time imagery that can be used for a variety of natural resource applications, including discrimination of individual plant species and vegetation types, assessing vegetative conditions, and environmental monitoring $(6,7)$.

To our knowledge, electronic imaging has not been used for detecting oak wilt disease. The objective of this article is to demonstrate the usefulness of aerial CIR digital imagery for distinguishing oak wilt disease in a live oak population in southcentral Texas.

\section{MATERIALS AND METHODS}

This study was conducted near Pleasanton, in south-central Texas. Pleasanton is located approximately $52 \mathrm{~km}$ south of San Antonio in the Rio Grande Plain vegetational region (11). The study site was a live oak forested area known to be affected by oak wilt disease. Aerial digital imagery, aerial photography, radiometric light reflectance measurements, and ground truth observations were conducted for this study. Reflectance measurements were made to help interpret the aerial imagery, while ground truth observations were conducted to verify aerial imagery.

Oak wilt disease was confirmed in trees at the study site from laboratory analysis of plant tissue samples. Laboratory procedures used for diagnosis were according to Appel and Maggio (3). Leaves from diseased trees typically had veinal necrosis and tipburn.

Radiometric light reflectance measurements were made on 10 randomly selected branches from each of three live oak tree conditions: (i) healthy, (ii) oak-wilt-diseased, and (iii) dead. The branches were removed from the trees and placed on the ground prior to obtaining spectral measurements. A Barnes modular multispectral radiometer was used for spectral measurements (21). Reflectance measurements were made in the visible green $(0.52$ to $0.60 \mu \mathrm{m})$, visible red $(0.63$ to $0.69 \mu \mathrm{m})$, and near-infrared (NIR) (0.76 to $0.90 \mu \mathrm{m})$ spectral bands with a boom-mounted sensor that had a $15^{\circ}$ field of view. Measurements were made at approximately $1.0 \mathrm{~m}$ above each sample. Spectral measurements were made between 1130 and 1400 hours under sunny conditions on 9 December 1997. Radiometric measurements were corrected to reflectance using a barium sulfate standard.

Aerial CIR digital imagery and photography were acquired concurrently of the study site. Kodak CIR $(0.50$ to $0.90 \mu \mathrm{m})$ type 2443 film was used for aerial photographs. Photographs were obtained with a Fairchild type K-37 large-format ( 23 by 23 $\mathrm{cm})$ mapping camera. The camera had an aperture setting of $\mathrm{f} 8$ at $1 / 250$ second and a 305-mm lens equipped with a Wratten 15 orange (minus blue) filter.

Table 1. Canopy light reflectance measurements of healthy, diseased, and dead live oak trees at the green, red, and near-infrared wavelengths. The diseased and dead trees had oak wilt disease. Measurements were made near Pleasanton, Texas in December 1997

\begin{tabular}{lccc}
\hline & \multicolumn{3}{c}{ Canopy reflectance for three wavelengths (\%) } \\
\cline { 2 - 4 } Tree condition & Green & Red & Near-infrared \\
\hline Healthy live oak & 3.8 & 2.6 & 34.6 \\
Diseased live oak & 5.3 & 4.3 & 26.0 \\
Dead live oak & 8.5 & 6.6 & 17.9 \\
LSD $^{\mathrm{a}}$ & 0.6 & 0.4 & 3.3 \\
\hline
\end{tabular}

${ }^{a}$ Least significant difference at 0.05 probability level. 

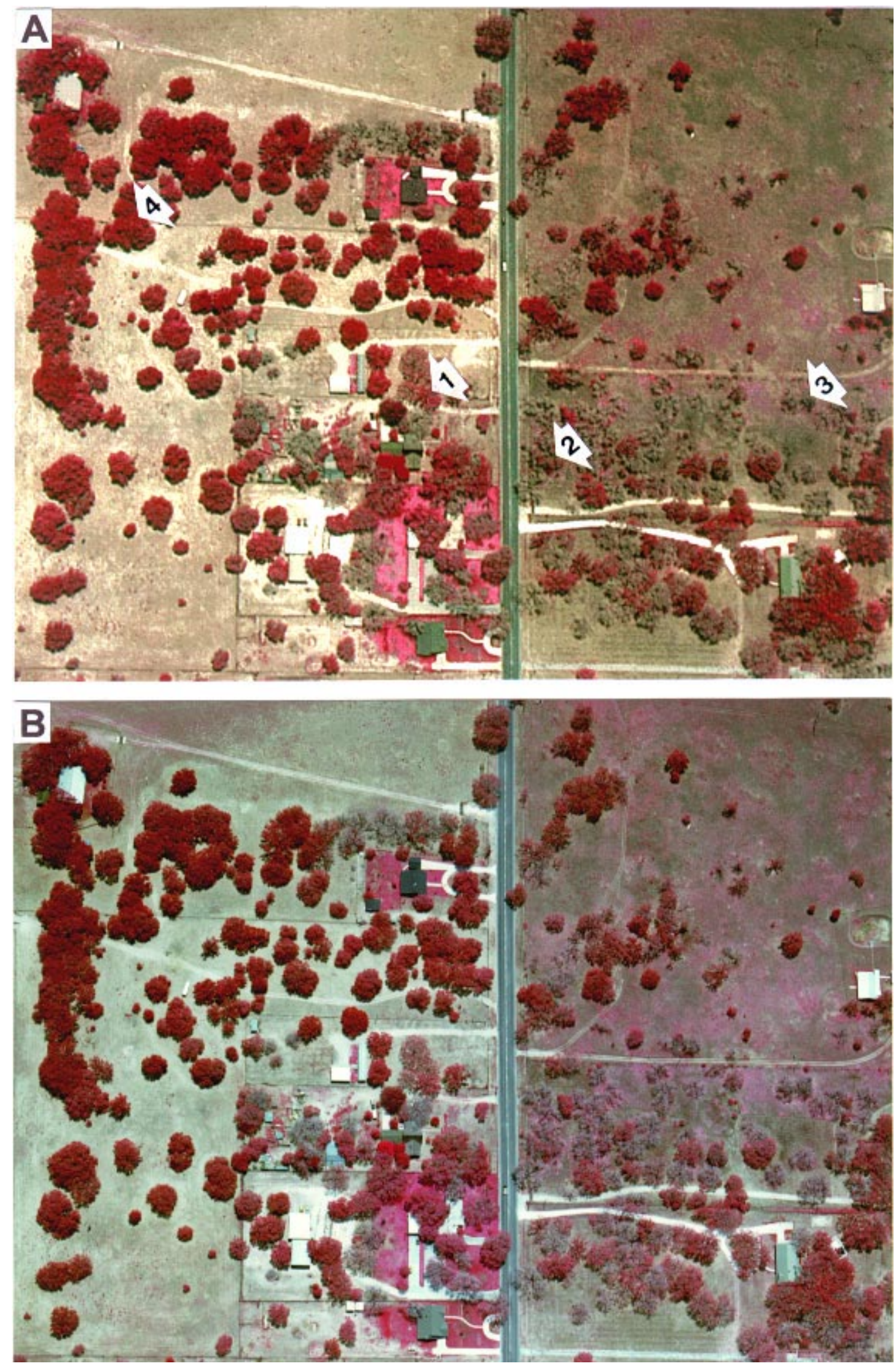

Fig. 1. (A) Color-infrared digital image and (B) color-infrared photograph of a live-oak-forested area near Pleasanton, Texas affected by oak wilt. The arrows on print A point to the following: arrow 1, live oak tree affected with early to moderate stages of oak wilt; arrow 2, live oak tree severely affected by oak wilt; arrow 3, dead live oak tree killed by oak wilt; and arrow 4, healthy live oak tree. The imagery was obtained at an altitude above ground level of $1,525 \mathrm{~m}$. 
Digital imagery was acquired with a true digital imaging system that is comprised of a computer and a frame mount with three black-and-white Kodak Megaplus 1.4i digital cameras (6). The cameras had noninterlaced charge-coupled device (CCD) sensors $(1,320$ horizontal by 1,035 vertical pixels) with visible to NIR light sensitivity ( 0.4 to $1.0 \mu \mathrm{m}$ waveband) and a built-in analog-digital converter that readily produces a digital video output signal containing 256 gray levels. The cameras were equipped with 12.0-mm focal length fixed lenses and narrow band interference filters. One camera had a NIR $(0.845$ to $0.857 \mu \mathrm{m})$ filter, the second camera had a visible red (R; 0.623 to $0.635 \mu \mathrm{m}$ ) filter, and the third camera had a visible yellow-green (YG; 0.555 to $0.565 \mu \mathrm{m})$ filter.

The computer was a Gateway 200 Pentium system (100 MHZ) that was interfaced with a versa module europa (VME) enclosure containing three image grabbing boards $(1,024$ by 1,024 pixels, one for each camera). The NIR, R, and YG digital images from the cameras were instantaneously transferred to the three respective grabbing boards in the VME enclosure, giving a digital CIR composite image similar in color rendition to that of CIR film. The computer had a 2-gigabyte storage capacity hard drive with the capability of storing approximately 500 color composite images. Imagery was obtained on 14 November 1997, and 16 January and 16 June 1998, at altitudes above ground level of approximately 1,525 and $3,050 \mathrm{~m}$. At the 1,525- and 3,050-m altitudes, the film images had scales of 1:5000 and 1:10000 and ground resolutions of 0.15 and $0.30 \mathrm{~m}$, respectively, whereas the digital imagery had ground pixel (resolution) sizes of 1.08 and $2.15 \mathrm{~m}$, respectively, at the same altitudes.

Reflectance data were subjected to analysis of variance and means were separated using the least significant difference (LSD) procedure (22). All statistical comparisons were made at the 0.05 probability level.

\section{RESULTS AND DISCUSSION}

Mean light reflectance values for leaves from healthy, oak wilt-diseased, and dead live oak branches at three wavelengths are presented in Table 1. Reflectance values were significantly different $(P=0.05)$ among the three conditions of live oak at each of the three spectral wavelengths. Foliage from healthy live oak branches had lower visible green and red reflectance than diseased leaves and dead branches. Diseased leaves had higher green and red reflectance values than healthy leaves and lower reflectance values than dead branches at these two visible wavelengths. The lower visible reflectance values of healthy live oak leaves was primarily attributed to their dark green color (higher chlorophyll), which absorbed more of the green and red light than the lighter green and mottled leaves (lower chlorophyll) of the diseased branches $(10,20)$. Leaves from the diseased branches were mottled with necrosis and tip burn, and many had an overall chlorotic appearance. The high visible reflectance value of the dead branches was attributed to their light gray color.

The NIR reflectance of healthy live oak leaves was higher than that of diseased leaves and dead branches (Table 1). Nearinfrared reflectance is highly correlated with vegetation density $(9,20,23)$. A qualitative analysis of the overhead photographs of the different conditions of branches showed that the foliage of the healthy live oak branches had greater leaf density and fewer gaps (sun flecks) between leaves than the oak wilt-infected branches; dead branches were leafless.

A CIR digital image and CIR photograph (Fig. 1A and B, respectively) were obtained on 16 June 1998 of a live oakforested area near Pleasanton, Texas affected by oak wilt disease. The imagery was obtained at an altitude of $1,525 \mathrm{~m}$. The typical light-red to grayish-magenta tonal response of a live oak tree with early to moderate stages of oak wilt is visible on the digital image (arrow 1). Severely affected trees (arrow 2) have a faint grayishmagenta image tone, while dead trees (arrow 3) are grayish in color. Healthy live oak trees (arrow 4) have a dark red color. A large stand of live oak trees killed by oak wilt, as well as several affected trees, occur in the lower right portion of the digital image. Other concentrations of dead and affected trees can be delineated in both the lower and upper center parts of the image. A predominantly healthy stand of live oak occurs in the left half of the image. The dark red color of healthy trees was primarily attributed to their higher NIR reflectance, but their low visible reflectance also contributed to their image response (Table 1). The light-red to grayish-magenta tones of the diseased trees was attributed to both their higher visible and lower NIR reflectances when compared to the healthy trees. The color responses of the healthy and unhealthy trees in the digital image (Fig. 1A) are comparable to those in the photograph (Fig. 1B). Although the digital image does not have the detailed resolution of the photograph, it clearly provides definitive recognition of the trees' features and conditions. Moreover, it is of adequate quality for assessing and distinguishing the affected and dead trees from the healthy trees. Slight tonal differences between the digital image and photograph are attributed to digital electronic coding versus the film emulsion layers.

Additional live oak trees affected by oak wilt disease could be distinguished at three other locations in the same area in June and had similar digital and photographic image responses to those shown in Figure
$1 \mathrm{~A}$ and B. Dead, diseased, and healthy trees could be distinguished in other CIR digital and photographic images obtained in this area in November 1997 and January 1998. Digital imagery acquired at $1,525 \mathrm{~m}$ was superior to that obtained at $3,050 \mathrm{~m}$ for distinguishing between healthy and diseased trees; however, dead trees could be equally delineated at both altitudes. Diseased and dead trees could be readily distinguished at both altitudes in the CIR photographs due to their finer resolution.

Our results showed that CIR digital imagery can be a useful tool for detecting oak wilt disease in live oak. In addition, the electronic format of the digital imagery allows it to be readily integrated into a geographic information system. These findings should be useful to natural resource managers interested in detecting and monitoring the presence and spread of oak wilt in live oak.

\section{ACKNOWLEDGMENTS}

We thank M. Alaniz for his assistance in acquiring field reflectance measurements and preparation of illustrations, and F. Gomez for helping obtain the aerial imagery.

\section{LITERATURE CITED}

1. Appel, D. N. 1986. Recognition of oak wilt in live oak. J. Arboric. 12:213-218.

2. Appel, D. N., Dees, C. F., and Johnson, J. 1985. An extended range for oak wilt and Ceratocystis fagacearum compatibility types in the United States. Can. J. Bot. 63:13251328 .

3. Appel, D. N., and Maggio, R. C. 1984. Aerial survey for oak wilt incidence at three locations in central Texas. Plant Dis. 68:661-664.

4. Appel, D. N., Maggio, R. C., Nelson, E. L., and Jeger, J. 1989. Measurement of expanding oak wilt centers in live oak. Phytopathology $79: 1318-1322$.

5. Ciesla, W. M., Dull, C. W., Wilson, E. T. and Mistretta, P. A. 1984. Panoramic aerial photography of oak decline and mortality in central Texas. USDA For. Serv. For. Pest Manage. Methods Appl. Group. Fort Collins, $\mathrm{CO}$.

6. Escobar, D. E., Everitt, J. H., Noriega, J. R., Davis, M. R., and Cavazos, I. 1997. A true digital imaging system for remote sensing applications. Pages 470-484 in: Proc. 16th Biennial Workshop on Videography and Color Photography in Resource Assessment. Am. Soc. Photogramm. Remote Sens. Bethesda, MD.

7. Everitt, J. H., Escobar, D. E., and Davis, M. R. 1995. Using remote sensing for detecting and mapping noxious plants. Weed Abstr 44:639-649.

8. Everitt, J. H., Escobar, D. E., and Noriega, J. 1991. A high resolution multispectral video system. Geocarto Int. 6(4):45-51.

9. Everitt, J. H., Richardson, A. J., and Nixon, P. R. 1986. Canopy reflectance characteristics of succulent and nonsucculent rangeland plant species. Photogramm. Eng. Remote Sens. 52:1891-1897.

10. Gausman, H. W. 1985. Plant leaf optical parameters in visible and near- infrared light. Graduate Studies Tex. Tech Univ. No. 29. Texas Tech Press, Lubbock.

11. Gould, F. W. 1975. Texas plants-a checklist and ecological summary. MP. 585, Tex. Agric. Exp. Stn., Tex. A \& M Univ., College Station.

12. Heller, R. C., and Ulliman, J. L. 1983. Forest resource assessments. Pages 2229-2324 in: 
Manual of Remote Sensing. R. N. Colwell, ed. Am. Soc. Photogramm., Falls Church, VA.

13. Hutchinson, C. F., Schowengert, R. A., and Baker, R. L. 1990. A two-channel multiplex video remote sensing system. Photogramm. Eng. Remote Sens. 56:1125-1128.

14. King, D. J. 1995. Development of an airborne multispectral digital frame camera sensor. Pages 13-22 in: Proc. 15th Biennial Workshop on Videography and Color Photography in Resource Assessment. Am. Soc. Photogramm. Remote Sens. Bethesda, MD.

15. King, D. J., and Vlcek, J. 1990. Development of a multispectral video system and its application in forestry. Can. J. Remote Sens. 16:15-22.

16. Latham, R. P., French, D. W., and Meyer, M. P. 1969. Detecting oak wilt by false color in- frared aerial photography. J. Minn. Acad. Sci. 36(1):14-15.

17. Lewis, R. 1977. Oak wilt in central Texas. (Abstr.) Proc. Am. Phytopathol. Soc. 4:225.

18. Lewis, R., and Oliveria, F. L. 1979. Live oak decline in Texas. J. Arboric. 11:241-244.

19. Lund, H. G., Befort, W. W., Brickell, J. E., Ciesla, W. M., et al. 1997. Forestry. Pages 399-440 in: Manual of Photographic Interpretation, 2nd edition. W. R. Phillipson, ed. Am. Soc. Photogramm. Remote Sens. Bethesda, MD.

20. Myers, V. I., Bauer, M. E., Gausman, H. W., Hart, W. G., Heilman, J. L., McDonald R. B., Park, A. B., Ryerson, R. A., Schmugge, T. J., and Westin, F. C. 1983. Remote sensing in agriculture. Pages 2111-2228 in: Manual of Remote Sensing, 2nd edition. R. N. Colwell, ed.
Am. Soc. Photogramm. Remote Sens. Bethesda, MD

21. Robinson, B. F., Bauer, M. E., DeWitt, D. P., Silva, L. F., and Vanderbilt, V. C. 1979. Multiband radiometer for field use. Pages 8-15 in: Measurements of Optical Radiations, SPIE Vol. 196, SPIE, Bellingham, WA.

22. Steel, R. G. D., and Torrie, J. H. 1980. Principles and procedures of statistics. McGrawHill Book Co., New York, NY.

23. Tucker, C. J. 1979. Red and photographic infrared linear combinations for monitoring vegetation. Remote Sens. Environ. 8:127150.

24. Ulliman, J. J., and French, D. W. 1977. Detection of oak wilt with color IR aerial photography. Photogramm. Eng. Remote Sens. 43:1267-1272. 